\title{
POTENSI ENERGI LISTRIK PADA PABRIK KELAPA SAWIT MELALUI PEMBANGUNAN PLTBG
}

\author{
Stieven N. Rumokoy ${ }^{1}$ dan Dezetty Monika ${ }^{2}$ \\ 1) Jurusan Teknik Elektro, Politeknik Negeri Manado \\ 2) Jurusan Teknik Elektro, Politeknik Negeri Jakarta \\ E-mail:1)rumokoy@polimdo.ac.id, ${ }^{2}{ }^{1}$ dezetty.monika@elektro.pnj.ac.id
}

\begin{abstract}
Palm oil mills will produce liquid waste which is often called POME (Palm Oil Mill Effluent). This waste if not handled properly will disrupt the environment, even though POME stores a large potential of energy that can be used to support energy needs. With special processing, POME can produce biogas. Then biogas can be used as fuel for generators and ultimately can produce electricity. The process of processing from POME to biogas can be formed in a Biogas Power Plant (PLTBg). The amount of electrical energy that can be generated depends on the amount of biogas formed, while the amount of biogas that will be obtained generally depends on the volume of POME and the content of COD (Chemical Oxigen Demand) in POME. In the sample factory, one year of data has been taken. From the results of the analysis of the prediction of the calculation of electricity energy in palm oil mills through the construction of Biogas Power Plants, the average predicted monthly biogas that can be obtained based on data is 279023,248 $\mathrm{Nm}^{3} \mathrm{CH}_{4} /$ month and maximum biogas that can be obtained based on the maximum processing of coconut mills oil palm is $506153.34 \mathrm{Nm}^{3} \mathrm{CH}_{4} /$ month. The average predictable generating capacity based on data is 1.3 MWe and the maximum capacity that can be built should be around 2.37 MWe.
\end{abstract}

Keywords : Palm Oil Waste, POME, Biogas, Renewable Energy, Metane

\begin{abstract}
ABSTRAK
Pabrik kelapa sawit akan menghasilkan limbah cair yang sering disebut POME (Palm Oil Mill Effluent). Limbah ini jika tidak ditangani dengan baik akan mengganggu lingkungan, padahal POME menyimpan potensi energi yang besar yang dapat dipergunakan untuk mendukung kebutuhan energi. Dengan proses pengolahan khusus, POME dapat menghasilkan biogas. Biogas kemudian dapat dimanfaatkan sebagai bahan bakar untuk genset biogas yang akhirnya dapat menghasilkan listrik. Proses pengolahan dari POME menjadi biogas dapat dibentuk dalam suatu Pembangkit Listrik Tenaga Biogas (PLTBg). Jumlah energi listrik yang dapat dihasilkan bergantung pada jumlah biogas yang terbentuk, sedangkan jumlah biogas yang akan diperoleh pada umumnya bergantung dari volume POME dan kandungan COD (Chemical Oxigen Demand) pada POME. Pada pabrik sampel, data satu tahun telah diambil. Dari hasil analisis prediksi perhitungan pendapatan energi listrik pada pabrik kelapa sawit melalui pembangunan PLTBg, rata-rata prediksi tiap bulan biogas yang dapat diperoleh berdasarkan data adalah $279023.248 \mathrm{Nm}^{3} \mathrm{CH}_{4}$ /bulan dan maksimum biogas yang dapat diperoleh berdasarkan maksimum pengolahan pabrik kelapa sawit adalah $506153.34 \mathrm{Nm}^{3} \mathrm{CH}_{4} /$ bulan. Rata-rata kapasitas pembangkit yang dapat diprediksi berdasarkan data adalah 1.3 MWe dan maksimum kapasitas yang dapat dibangun sebaiknya sekitar 2.37 MWe.
\end{abstract}

Kata kunci : Limbah, POME, Biogas, Energi Baru dan Terbarukan, Metana

\section{PENDAHULUAN}

Kelapa sawit masih menjadi salah satu motor penggerak perekonomian nasional. Sampai Desember 2014 diperkirakan total nilai ekspor mencapai USD\$ 20,8 miliar, meningkat 8\% dibandingkan dengan total nilai ekspor tahun 2013 yaitu USD\$ 19,23 milliar. Dengan jumlah produksi 31 juta ton pada tahun 2014 potensi limbah yang dihasilkan juga sangat besar [1]. Limbah cair kelapa sawit dikenal dengan POME (Palm Oil Mill Effluent) tidak boleh langsung dibuang ke sungai. Melalui Keputusan Menteri Negara Lingkungan 
Hidup Nomor 51/1995, Pemerintah mengatur tingkat kandungan yang diperbolehkan dalam POME yang telah diolah untuk dibuang langsung ke sungai. Untuk memenui standar peraturan tersebut, pabrik kelapa sawit harus mengolah POME sebelum dibuang ke sungai. Proses pengolahan ini akan menghasilkan biogas, yang jika dilepaskan begitu saja akan menyebabkan pencemaran udara. Oleh karena itu, PLTBg memanfaatkan biogas dari pengolahan POME selain mengurangi pelepasan biogas ke udara juga menghasilkan listrik sebagai sumber energi yang dapat dimanfaatkan [2].

Ketika limbah cair kelapa sawit (POME) teruraikan maka secara alami akan menghasilkan biogas. Biogas biasanya terdiri dari $50-75 \%$ metana $\left(\mathrm{CH}_{4}\right)$, 25$45 \%$ karbon dioksida $\left(\mathrm{CO}_{2}\right)$, dan sejumlah kecil gas-gas lainnya. Jika gas metana di dalam biogas terlepas langsung ke atmosfer, maka akan menimbulkan gas rumah kaca. Hal ini dikarenakan, gas metana mempunyai efek 21 kali lebih besar dibandingkan dengan gas $\mathrm{CO}_{2}$. Mengubah POME menjadi biogas untuk dibakar dapat menghasilkan energi sekaligus mengurangi dampak perubahan iklim dari proses produksi minyak kelapa sawit dan hal ini belum banyak dimanfaatkan di Indonesia. Tabel 1 menunjukkan potensi daya dari konversi POME menjadi biogas yang dihasilkan oleh pabrik kelapa sawit.[3]
Tabel 1. Proyeksi potensi daya dari POME berdasarkan kapasitas PKS

\begin{tabular}{|c|c|c|c|}
\hline \multirow{2}{*}{$\begin{array}{l}\text { Kapasitas PKS } \\
\text { (ton TBS/jam) }\end{array}$} & \multicolumn{2}{|c|}{ POME yang D'hasilkan } & \multirow{2}{*}{$\begin{array}{l}\text { Potensi Daya } \\
\text { (MWe) }\end{array}$} \\
\hline & $\mathrm{m}^{3} / \mathrm{jam}$ & $\mathrm{m}^{3} /$ hari & \\
\hline 30 & 21 & 400 & 1,1 \\
\hline 45 & 31,5 & 600 & 1,6 \\
\hline 60 & 42 & 800 & 2,1 \\
\hline 90 & 63 & 1200 & 3,2 \\
\hline \multicolumn{4}{|c|}{ Total Potensi di Indonesia } \\
\hline 34.280 & 23.996 & 479.920 & 1.280 \\
\hline
\end{tabular}

Berdasarkan proyeksi tersebut, pemakalah memprediksi potensial energi yang didapatkan dari limbah cair kelapa sawit (POME) yang dapat digunakan untuk mendukung kebutuhan energi pabrik kelapa sawit.

\section{METODE PENELITIAN}

Pada penelitian ini, metode penelitian yang dilakukan adalah observasi lapangan dan kajian lapangan. Tinjauan lapangan dan data output adalah data satu tahun pada salah satu sampel Pabrik Kelapa Sawit (PKS). Studi literature yang dilakukan dengan mempelajari pembentukan biogas dan mengenai engine biogas.

\section{a. Pabrik Kelapa sawit}

Pabrik kelapa Sawit (PKS) adalah tempat pengolahan Tandan Buah Segar (TBS) sawit untuk mengasilkan minyak mentah sawit atau sering disebut CPO (Crude Palm Oil). Pada proses pengolahan TBS menjadi CPO melalui beberapa tahap. Secara garis besar proses pengolahan dibagi tahap demi tahap disetiap stasiun yang ada pada PKS. Pada pabrik kelapa sawit pada umumnya terdapat stasiun loading ramp tempat pengumpulan, pemilahan dan persiapan untuk TBS yang akan diolah. Stasiun sterilizer sebagai tempat perebusan TBS. Stasiun tippler dan tresher adalah tempat pemipilan buah dari tandan buah sawit, stasiun press untuk pemisahan minyak sawit dari daging buah dan stasiun klarifikasi 
sebagai tempat pemurnian untuk mendapakan CPO. Saat proses inilah menghasilkan limbah cair/POME.

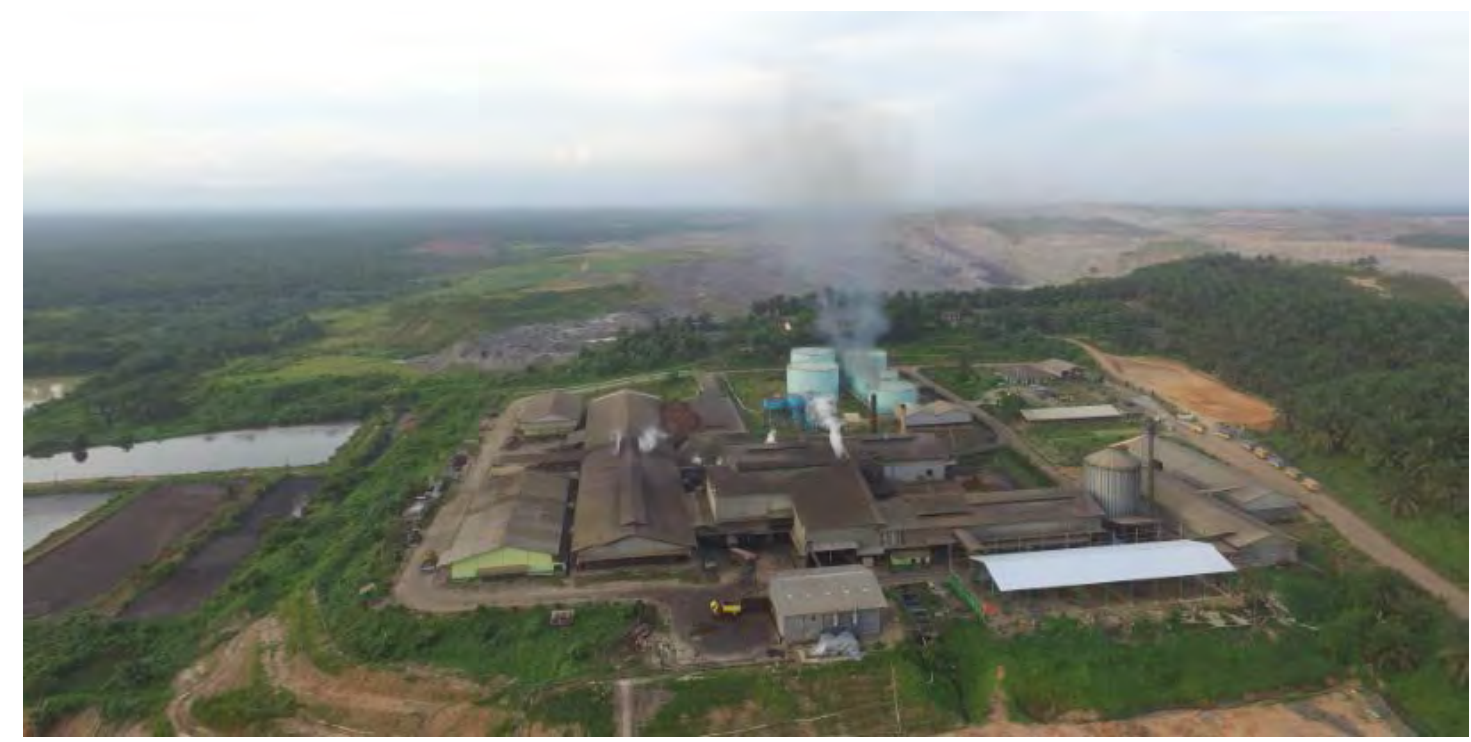

Gambar 1. Pabrik kelapa sawit

\section{b. POME}

Pada Pabrik Kelapa Sawit yang menghasilkan Minyak Mentah atau Crude Palm Oil (CPO) akan menghasilkan limbah cair. Limbah cair hasil produksi disebut POME (Palm Oil Mill Effluent). POME yang dihasilkan ini terjadi pada Proses sterilisasi Tandan Buah Segar (TBS) sawit dan proses penjernihan minyak sawit mentah. POME yang dihasilkan dari Pabrik Kelapa Sawit (PKS) pada umumnya memiliki suhu sekitar $60^{\circ}$ sampai $80^{\circ}$ memiliki pH sekitar 3.3 - 4.6, warnanya coklat.

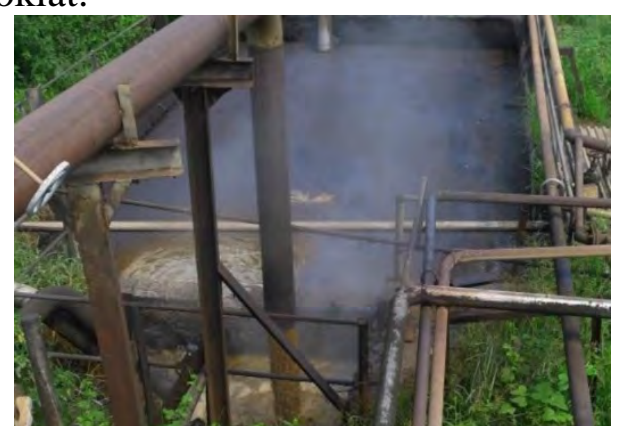

Gambar 2. POME (Palm Oil Mill Effluent)

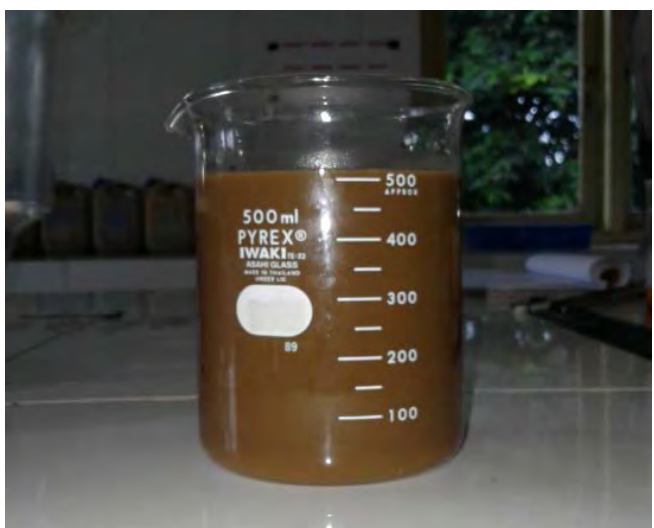

Gambar 3. Sampel POME di gelas ukur

\section{c. Biogas}

Pada Biogas pada umumnya terkandung sekitar 50\% sampai $75 \%$ metana $\left(\mathrm{CH}_{4}\right)$, sekitar 25\% sampai 45\% adalah karbon dioksida $\left(\mathrm{CO}_{2}\right)$ dan sejumlah kecil gas lain seperti uap air $\left(\mathrm{H}_{2} \mathrm{O}\right)$, Nitrogen (

$\mathrm{N}^{2}$ ) dan lainnya. Dibandingkan dengan udara, biogas lebih ringan sekitar 20\%. Temperatur nyala biogas ada pada berkisar $650^{\circ} \mathrm{C}$ sampai $750^{\circ} \mathrm{C}$. Volume biogas biasanya diukur dalam Normal Meter kubik $\left(\mathrm{Nm}^{3}\right)$ yang berarti volume 
gasnya diukur pada tekanan atmosfir dengan suhu $0^{\circ} \mathrm{C}$.

Pada pembentukan biogas melalui proses anaerobik, terdapat beberapa tahap pengurian. Tahap penguraian meliputi:

\section{1). Hidrolisis}

Pada tahap ini, air akan bereaksi dengan polimer organik rantai panjang yang seperti lemak, polisakarida dan protein kemudian akan membentuk polimer berantai pendek yang dapat larut. Polimer berantai pendek yang dapat larut berupa asam lemak, asam amino, gula dan lainnya. Mikroorganisme menghasilkan enzim selulose, amylase, lipase atau protase pada tahap ini.

\section{2). Asidogenesis}

Pada fase asidogenesis akan terjadi oksidasi anaerobik dengan menggunakan gula, asam lemak rantai panjang dan asam amino yang terbentuk dari proses sebelumnya. Ada banyak bakteri yang berbeda pada proses asidogenesis ini. Seringkali tahap ini adalah tahap tercepat dalam mengkonversi zat organic kompleks selama penguraian dalam fase cair. Bakteri yang ada akan bereaksi terhadap meningkatnya konsentrasi hydrogen pada cairan dengan menghasilkan laktat, etanol, propionate, butiran dan asam lemak volatile (VFA), yang kemudian digunakan oleh mikroorganisme metanogen sebagai substrat.

\section{3). Asetogenesis}

Pada tahap ini, bakteri asetogenik yang menghasilkan hydrogen akan mengkonversi asam lemak dan etanol/alkohol menjadi asetat, karbondioksida juga hydrogen. Asetogen yang ada akan bertumbuh lambat dan bergantung pada tekanan parsial hydrogen yang rendah sebagai pendegradasi asetogenik yang menghasilkan energi. Asetogen termasuk sensitif terhadap perubahan lingkungan.

\section{4). Metanogenesis}

Pembentugan gas metana melalui dua bagian utama yaitu bagian primer dan sekunder. Pada bagian primer fermentasidari produk utama dari tahap pembentukan asam yakni asam asetat berubah menjadi metana dan karbon dioksida. Bakteri yang berperan dalam proses ini adalah bakteri asetoklastik (asetofilik). Bagian sekunder adalah penguraian yang menggunakan hydrogen untuk mengurangi $\mathrm{CO}_{2}$ dan kemudian menghasilkan $\mathrm{CH}_{4}$ dengan metanogen hidrogenofilik.

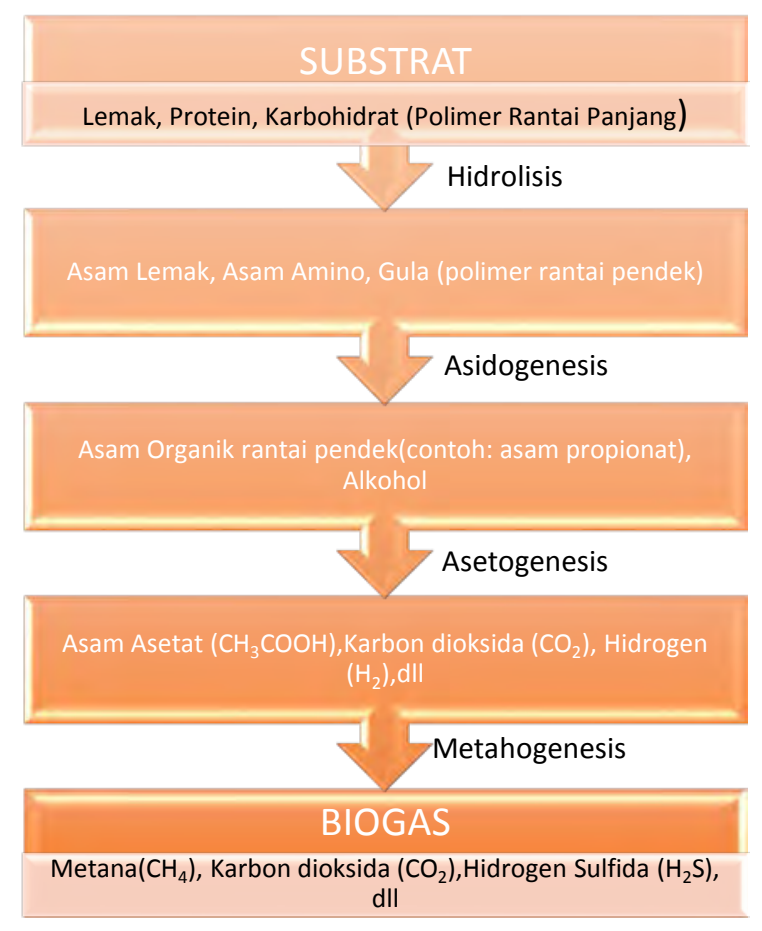

Gambar 4 Tahapan pembentukan biogas

\section{HASIL DAN PEMBAHASAN}

Pada penelitian ini, tahap demi tahap yang dilakukan untuk mendapatkan hasil yang ingin diketahui adalah dengan melakukan langkah seperti pada gambar berikut: 


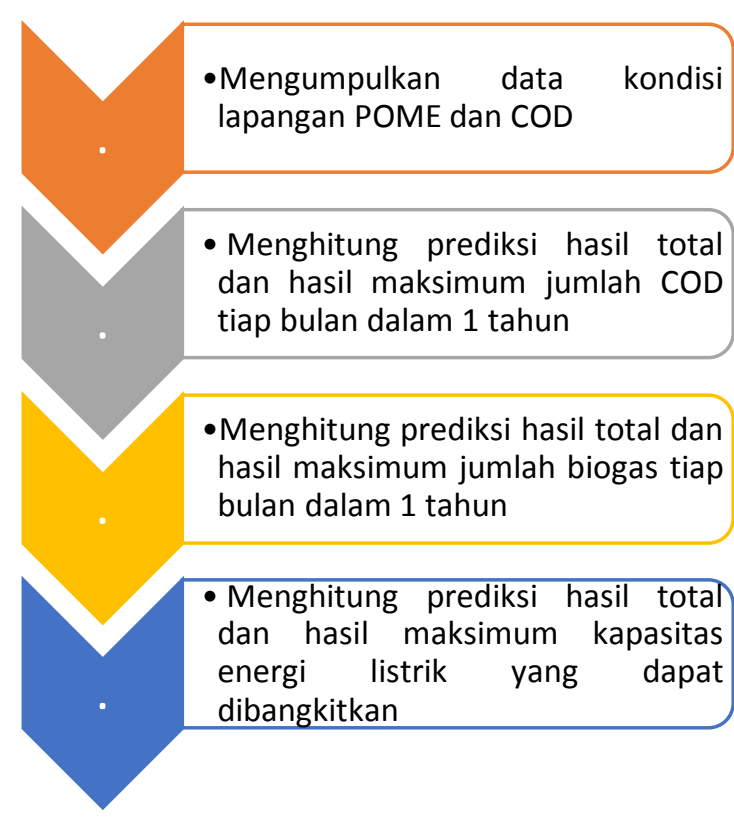

Gambar 7. Tahapan energi listrik yang dapat dibangkitkan

\section{a. Produksi POME dan kandungan COD}

Pada pabrik kelapa sawit dengan kapasitas 60 ton/jam pengolahan tandan buah sawit, pada umumnya dapat menghasilkan $0.7 \% \mathrm{~m}^{3}$ POME dari perbandingan total tonase pengolahan pengolahan tandan buah sawit. Maksudnya jika tandan buah sawit yang diolah adalal 1000 ton, maka POME yang dihasilkan berkisar $700 \mathrm{~m}^{3}$. Jumlah POME yang dihasilkan dari pabrik kelapa sawit bergantung pada teknologi yang digunakan pabrik kelapa sawit. Teknologi pengolahan minyak mentah sawit atau Crude Palm Oil yang menghasilkan limbah POME yang lebih sedikit dipandang lebih efisien karena penggunaan air untuk proses produksi akan lebih sedikit. Dari data yang ada pada pabrik sample ini, data hasil POME yang diperoleh setiap bulannya dibandingkan dengan rata-rata COD yang diukur adalah:
Tabel 2. Data sample POME dan COD

\begin{tabular}{|c|c|c|}
\hline Bulan & $\begin{array}{c}\text { Data } \\
\text { POME } \\
\text { produksi } \\
\left(\mathrm{m}^{3}\right)\end{array}$ & $\begin{array}{c}\text { Data } \\
\text { COD } \\
\text { Terukur } \\
(\mathrm{ppm})\end{array}$ \\
\hline Januari & 13060 & 74809 \\
\hline Februari & 9912 & 76383 \\
\hline Maret & 14523 & 75412 \\
\hline April & 11246 & 91053 \\
\hline Mei & 13128 & 88511 \\
\hline Juni & 10712 & 73111 \\
\hline Juli & 12241 & 74443 \\
\hline Agustus & 9821 & 77479 \\
\hline September & 11682 & 75558 \\
\hline Oktober & 10653 & 68115 \\
\hline November & 10112 & 71678 \\
\hline Desember & 11525 & 71647 \\
\hline Total/Average & 138615 & 76516.58 \\
\hline
\end{tabular}

Dari data diatas jumlah POME yang dihasilkan dapat dikatakan tidak banyak. Jika pabrik kelapa sawit dengan kapasitas 60 ton/jam berperasi 20 jam setiap hari, maka total pengolahan akan mencapai 1200 ton tandan buah sawit yang dapat diolah. Jika dalam 1 bulan hari efektif pengolahan ditargetkan 25 hari, maka dalam satu bulan tandan buah sawit yang dapat diolah adalah 30000 ton tandan buah sawit. Jika perbandingan tandan buah segar dengan POME yang dihasilkan adalah 0.7, maka jumlah POME yang dapat dihasilkan oleh Pabrik Kelapa Sawit (PKS) mencapai $21000 \mathrm{~m}^{3}$ tiap bulannya. Jika data hasil POME dengan pengolahan efektif dibandingkan dengan POME real, maka pada kondisi diatas diperoleh keterangan bahwa pabrik tidak berproduksi seperti pada umumnya. Kondisi ini dapat terjadi karena hasil buah dari kebun yang masuk ke Pabrik Kelapa Sawit sedang menurun.COD yang terkandung pada POME menunjukan angka yang baik untuk bahan baku penghasil biogas. Pada rata- 
rata COD dalam produksi tiap bulan dalam satu tahun adalah 76516 ppm.

\section{b. Total COD per bulan}

Untuk memprediksi total biogas yang dapat dihasilakan untuk digunakan sebagai bahan bakar engine biogas yang kemudian dapat menghasilkan listrik, dibutuhkan prediksi Total COD yang diperoleh. Jika menggunakan data dari produksi POME dan data COD-nya, maka total COD tiap bulannya dengan prediksi dapat dilihat pada tabel berikut.

Tabel 3. Total perkiraan COD yang dihasilkan

\begin{tabular}{|c|c|}
\hline Bulan & $\begin{array}{c}\text { Perkiraan } \\
\text { Total } \\
\text { COD/bulan }\end{array}$ \\
\hline Januari & 977005.5 \\
\hline Februari & 757108.3 \\
\hline Maret & 1095208 \\
\hline April & 1023982 \\
\hline Mei & 1161972 \\
\hline Juni & 783165 \\
\hline Juli & 911256.8 \\
\hline Agustus & 760921.3 \\
\hline September & 882668.6 \\
\hline Oktober & 725629.1 \\
\hline November & 724807.9 \\
\hline Desember & 825731.7 \\
\hline Total/Average & 10629457.1 \\
\hline
\end{tabular}

Jika dibandingakan dengan kemampuan maksimum pengolahan Pabrik Kelapa Sawit (PKS) menghasilkan POME tiap bulannya yaitu $21000 \mathrm{~m}^{3}$ dan prediksi COD tiap bulannya menggunakan data rata-rata dari hasil pengolahan yang ada yaitu 76516.58 ppm, maka dapat diprediksi total COD tiap bulannya mencapai 1606836 COD/bulan.

\section{c. Prediksi Hasil Biogas}

Untuk mendapatkan prediksi Biogas yang dapat dihasilkan, persamaan yang dapat digunakan adalah[3]:

$$
\mathrm{CH}_{4} \text { Prod }=\mathrm{COD} \times \mu_{C O D} \times \alpha
$$

Dimana, $\mathrm{CH}_{4}$ Prod adalah total perkiraan biogas yang dapat dihasilkan ( $\mathrm{Nm}^{3} \mathrm{CH}_{4} /$ bulan), $\mu_{C O D}$ adalah efisiensi penguraian COD pada pengolahan limbah cair pada PLTBg atau dapat dikatakan perbandingan antara COD input dan COD output (\%), $\alpha$ adalah rasio $\mathrm{CH}_{4}$ terhadap COD sebesar 0.35.

Dengan menggunakan efisiensi penguraian COD pada umumnya mencapai sekitar 90\%, maka prediksi total biogas yang dapat diperoleh baik berdasarkan data yang ada dan prediksi maksimum dapat dilihat pada tabel 4 .

Tabel 4. Prediksi total biogas yang dapat dihasilkan.

\begin{tabular}{|c|c|c|c|}
\hline Bulan & Biogas prod & Biogas Max Prod & $\%$ \\
\hline Januari & 307756.745 & 506153.34 & 60.80307 \\
\hline Februari & 238489.113 & 506153.34 & 47.11796 \\
\hline Maret & 344990.67 & 506153.34 & 68.15932 \\
\hline April & 322554.342 & 506153.34 & 63.72661 \\
\hline Mei & 366021.309 & 506153.34 & 72.31431 \\
\hline Juni & 246696.985 & 506153.34 & 48.73957 \\
\hline Juli & 287045.88 & 506153.34 & 56.71125 \\
\hline Agustus & 239690.197 & 506153.34 & 47.35525 \\
\hline September & 278040.595 & 506153.34 & 54.93209 \\
\hline Qdtober & 228573.165 & 506153.34 & 45.15888 \\
\hline November & 228314.5 & 506153.34 & 45.10777 \\
\hline Desember & 260105.478 & 506153.34 & 51.38867 \\
\hline Average & 279023.248 & 506153.34 & 55.12623 \\
\hline
\end{tabular}

Perbandingan dari total prediksi produksi biogas yang dapat dihasilkan dengan maksimum biogas yang dapat diperoleh sekitar 55.13\%, ini menjelaskan bahwa hasil prediksi Biogas memang tergantung pada pengolahan yang dilakukan Pabrik Kelapa Sawit. Untuk lebih jelasnya perbandingan data, dapat dilihat pada gambar berikut. 


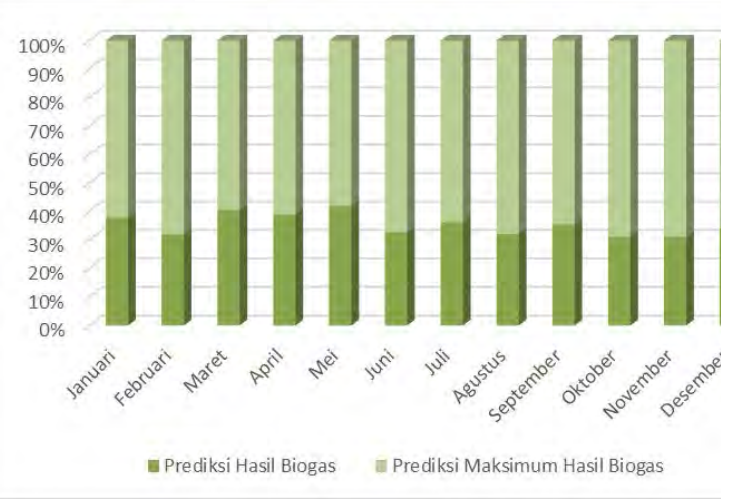

Gambar 8. Prediksi biogas yang dapat dihasilkan

\section{d. Prediksi Hasil Energi Listrik}

Dengan mendapatkan prediksi biogas yang dapat diperoleh, Prediksi untuk energi listrik yang dapat dihasilkan dapat dilakukan. Untuk menghitung jumlah energi listrik yang diperoleh dan kapasitas pembangunan PLTBg yang dapat dilakukan dapat dihitung dengan persamaan:[3]

$$
\begin{aligned}
& \text { Kapasitas Pembangkit } \\
& =\frac{\mathrm{CH}_{4} \text { Prod } \times \mathrm{CH}_{4, e v} \times \mathrm{Gen}_{\text {eff }}}{24 \times 60 \times 60 \times 30}
\end{aligned}
$$

Dimana, kapasitas pembangkit adalah kapasitas PLTBg yang dapat dibangun dari hasil energi yang dapat diperoleh (MWe), $\mathrm{CH}_{4}$ Prod adalah total biogas yang dapat diperoleh dalam 1 bulan ( $\mathrm{Nm}^{3} \mathrm{CH}_{4} /$ bulan), $\mathrm{CH}_{4, \text { ev }}$ adalah nilai energi metana $\left(35.7 \mathrm{MJ} / \mathrm{m}^{3}\right)$ dan $\mathrm{Gen}_{\text {eff }}$ adalah efisiensi generator biogas (34\%). Prediksi perolehan energi yang dapat dihasilkan adalah:
Tabel 5. Prediksi jumlah energi yang dapat diperoleh

\begin{tabular}{|c|c|c|c|}
\hline Bulan & Mwe & Max Mwe & $\%$ \\
\hline Januari & 1.44118494 & 2.370250479 & 60.80307 \\
\hline Februari & 1.1168136 & 2.370250479 & 47.11796 \\
\hline Maret & 1.61554659 & 2.370250479 & 68.15932 \\
\hline April & 1.51048017 & 2.370250479 & 63.72661 \\
\hline Mei & 1.71403034 & 2.370250479 & 72.31431 \\
\hline Juni & 1.15525 & 2.370250479 & 48.73957 \\
\hline Juli & 1.34419865 & 2.370250479 & 56.71125 \\
\hline Agustus & 1.12243812 & 2.370250479 & 47.35525 \\
\hline September & 1.30202806 & 2.370250479 & 54.93209 \\
\hline Obtober & 1.0703785 & 2.370250479 & 45.15888 \\
\hline November & 1.06916721 & 2.370250479 & 45.10777 \\
\hline Desember & 1.21804023 & 2.370250479 & 51.38867 \\
\hline Average & 1.3066297 & 2.370250479 & 55.12623 \\
\hline
\end{tabular}

Dari data diatas, prediksi rata-rata kapasitas yang dapat dibangkitkan bedasarkan data yang diperoleh adalah 1.3 MWe dan Maksimumnya adalah 2.37 MWe. Perbandingan jumlah kapasitas energi yang dapat diperoleh dapat dilihat pada gambar 9 .

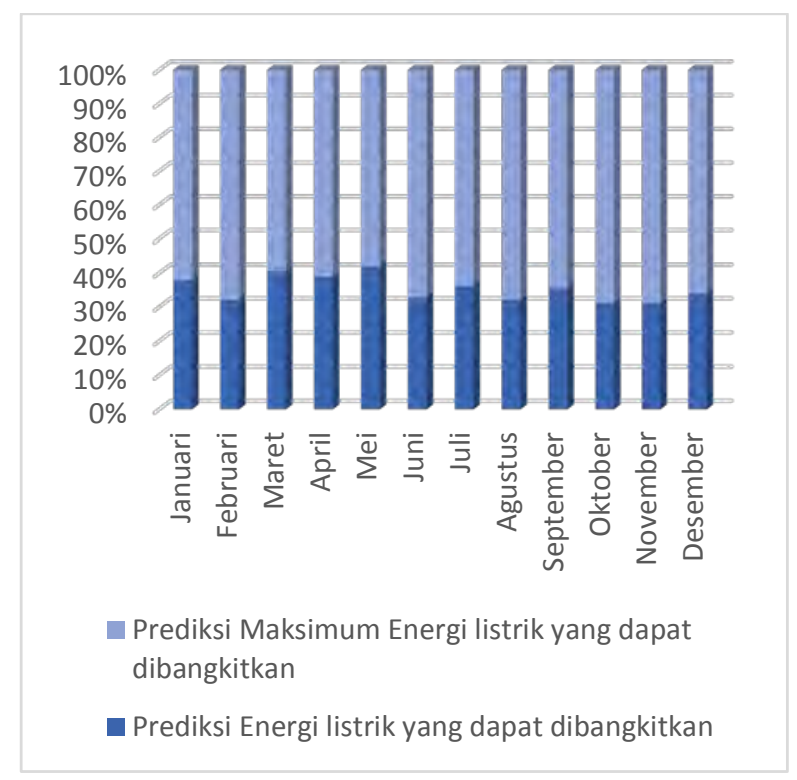

Gambar 9. Perbandingan kapasitas pembangkit yang dapat diperoleh. 


\section{KESIMPULAN}

Dari hasil prediksi perhitungan pendapatan energi listrik pada pabrik kelapa sawit melalui pembangunan PLTBg dapat diambil kesimpulan:

1. Rata-rata prediksi tiap bulan biogas yang dapat diperoleh berdasarkan data adalah 279023.248 $\mathrm{Nm}^{3} \mathrm{CH}_{4} /$ bulan dan maksimum biogas yang dapat diperoleh berdasarkan maksimum pengolahan pabrik kelapa sawit adalah 506153.34 $\mathrm{Nm}^{3} \mathrm{CH}_{4} /$ bulan.

2. Rata-rata kapasitas pembangkit yang dapat diprediksi berdasarkan data adalah 1.3 MWe dan maksimum kapasitas yang dapat dibangun sebaiknya sekitar 2.37 MWe.

\section{DAFTAR PUSTAKA}

[1] Afif, "BIOGAS KELAPA SAWIT,” 2015.

[2] Pembiayaan Pembangkit Listrik Tenaga Biogas. 2016.

[3] A. S. Rahayu, D. Karsiwulan, H. Yuwono, and I. Trisnawati, Konversi POME Menjadi Biogas. Winrock International, 2015. 